\title{
Aquatic invertebrate assemblages in ponds from coastal Mediterranean wetlands
}

\author{
Maria Anton-Pardo ${ }^{1 *}$ and Xavier Armengol ${ }^{2}$ \\ 1 University of South Bohemia in České Budějovice, Faculty of Fisheries and Protection of Waters, South Bohemian Research Centre \\ of Aquaculture and Biodiversity of Hydrocenoses and Research Institute of Fish Culture and Hydrobiology, Husova tř. 458/102, \\ 37005 České Budějovice, Czech Republic \\ ${ }^{2}$ Department of Microbiology and Ecology/ICBiBE, University of Valencia, Dr Moliner 50, 46100 Burjassot, Spain
}

Received 7 November 2013; Accepted 9 May 2014

\begin{abstract}
Invertebrate aquatic assemblages in ponds from Mediterranean wetlands are composed of organisms belonging to different taxonomic groups, which present a wide range of sizes (from small rotifers to large crustaceans or insects). Although they are often sampled and analyzed separately, the ecological links among these organisms should be considered, especially in very shallow waters. In our study, invertebrate assemblages (including micro-, macrozooplankton and macroinvertebrates) were characterized in eight shallow lakes from Mediterranean wetlands in Southeastern Spain. A great spatial and temporal variability in the assemblages and in some environmental features was observed. The community was dominated in abundance and species richness by rotifers in most of the water bodies. Fish greatly contributed to the differences in community composition, as fishless ponds presented abundant and diverse cladoceran populations. Nutrient and chlorophyll- $a$ concentration, conductivity and macrophyte cover had also a great influence on these assemblages, especially in micro- and macrozooplankton. The temporal changes observed in some of these variables affect the proportion of invertebrate biomass of the different groups along the study period. All this environmental heterogeneity produces similar responses in the invertebrate groups, in general well adapted to salinity changes or high trophic conditions. Although the heterogeneity and human disturbances can increase regional diversity, they can cause the disappearance of valuable habitats, and finally, the homogeneity in invertebrate assemblages.
\end{abstract}

Key words: Conductivity / zooplankton / fish / rotifers / malacostraceans

\section{Introduction}

In very shallow water bodies, water column is quite homogeneous and the influence of environmental variables is prominent, causing important temporal variations (Scheffer, 2004). In the Mediterranean region where lakes are usually scarce, these shallow habitats are quite common, and most of them are located on coastal areas, so the prevalence of brackish water bodies is high (Boix et al., 2007; Sahuquillo et al., 2007). Owing to their shallowness, benthic and pelagic habitats are strongly linked (Vadeboncoeur et al., 2001), but despite this relationship, these habitats are often treated independently. The composition and abundance of the invertebrate assemblages of these ecosystems is greatly influenced by environmental variability, and especially by hydrological changes, typical of this region (Nielsen et al., 2002; Antón-Pardo and

*Corresponding author: pardo@frov.jcu
Armengol, 2010). Salinity could also determine community composition among sites with contrasting salinities, but it can also promote seasonal variations in each water body, related to water level changes (Boronat et al., 2001; Frisch et al., 2006). Moreover, in the Mediterranean region, and particularly in its coastal areas, human activity has led to heavy modifications in wetlands, mainly caused by the input of nutrients and contaminants from agricultural areas or sewage waters, but even producing the drainage and the disappearance of many of them (Pearce and Crivelli, 1994; Grillas et al., 2004). Nowadays, these human alterations are among the main factors influencing the structure of these aquatic assemblages (e.g., Pearce and Crivelli, 1994; Rodrigo et al., 2003).

In addition, biotic factors, as the presence of macrophytes and fish, could have strong effects on these aquatic assemblages (Scheffer, 2004; Rennie and Jackson, 2005; Claps et al., 2011). On the one hand, fish are the main visual predators, and through selective predation on larger 
invertebrates and organisms with lower scape velocity, they can influence the size structure and composition of the aquatic community (Brooks and Dodson, 1965; Hall et al., 1976). On the other hand, macrophytes increase the habitat heterogeneity and provide refuge and food for planktonic and benthic invertebrates (Burks et al., 2002; Meerhoff et al., 2007). Both, biotic and abiotic factors produce variable responses, determining the establishment and persistence of different assemblages (Doi et al., 2013).

In Mediterranean coastal lakes, the macroinvertebrate community with good swimming capacity consists mainly of some crustacean groups (amphipods, isopods, decapods, etc.) as well as adult and larval insects (Boix et al., 2007; Sahuquillo et al., 2007). These organisms can move through the water column faster than smaller planktonic organisms (as rotifers or cladocerans), and in very shallow systems, they can use the sediment or the vegetation as a refuge against predation (Romare et al., 2003). Thus, their abundance is frequently difficult to estimate when the whole water column (including watersediment interface) is not completely sampled. In addition, the sampling methodology or the microhabitat sampled are often determinant to estimate the different community parameters (García-Criado and Trigal, 2005; Florencio et al., 2012). Quantitative studies on aquatic invertebrates are mostly focused on microzooplankton (e.g., rotifers and juvenile copepods), macrozooplankton (e.g., adult copepods and cladocerans) or macroinvertebrates (e.g., bigger crustaceans and insects) separately, and usually interactions among them have not been largely considered. Additionally, the big differences in size among all these invertebrates could underestimate the influence of rare organisms with bigger biomass (Quintana et al., 2006).

Therefore, the main objective of this work is the characterization of the aquatic invertebrate assemblages in the whole water column (including rotifers, crustaceans and insects) in a set of very shallow ( $<1 \mathrm{~m}$ depth) coastal lakes. Our specific objectives are: (i) to study which environmental variables are influencing the structure of these assemblages; (ii) to investigate the effect of fish and (iii) to study the temporal variations of some abiotic and biotic variables in these ponds.

\section{Methods}

\section{Study site}

The study was carried out in Southeast Spain, an area with several wetlands remaining from an old coastal lagoon in the flood plain of the rivers Segura and Vinalopó (Viñals et al., 2001). These aquatic ecosystems are subjected to high anthropic pressure and are severely threatened by eutrophication, salinization and drying. Despite all this, they are important breeding and wintering areas for a large number of bird species (Atienzar et al., 2012), so most of them are protected by national and international conventions (e.g., RAMSAR, Special Protection Area by the European Union, etc.).
Our study was conducted in eight shallow lakes in three of these protected wetlands: (I) El Hondo Natural Park, (II) Salinas de Santa Pola Natural Park and (III) Clot de Galvany Local Natural Place (Fig. 1).

(I) El Hondo Natural Park has two large reservoirs surrounded by several brackish ponds. One of the reservoirs was dry during the study period, whereas the other, Levante Reservoir (EL), had water only occasionally. Four of the surrounding ponds were also selected: Reserva pond (RE); Southwest pond (WP); North pond (NO) and Saladar pond (SA). All these ponds presented high macrophyte development in spring and summer, and except SA, all are connected by channels. SA was artificially constructed in 2001, to create a suitable habitat for the endangered waterbird Marmaronetta angustirostris. The water used to fill this pond comes from a brackish aquifer.

(II) Salinas de Santa Pola Natural Park (Fig. 1) has several brackish ponds used for hunting, fishing and as salt works. Two of these ponds were selected: Santa Fe (SF) and Charcol $(\mathrm{CH})$. In both, the water level was artificially maintained, mainly for fishing.

(III) In Clot de Galvany Local Natural Place (Fig. 1) one small pond was sampled: Contacto Pond (GC), which was filled with freshwater from a sewage treatment plant without tertiary treatment. More information about the study area is detailed in Rodrigo et al. (2001), Viñals et al. (2001), Armengol et al. (2008) and Atienzar et al. (2012).

Although fish were not sampled in the present work, some information about them is available (Jiménez et al., 2002). In two of the studied ponds, fish were absent (GC) or presented very low densities (EL). In EL, fish were not observed during the study period, although they could have entered in low densities through the canal used to fill it. However, in the rest of the studied habitats, high densities of fish could be observed. In both ponds from Salinas de Santa Pola (SF and $\mathrm{CH}$ ), individuals of Mugil sp. and Liza sp. were the predominant fish. In El Hondo, all the connected brackish ponds (RE, WP and NO) had dense populations of large fish: Mugil sp., Liza sp., Anguilla anguilla (Linnaeus, 1758); but also small fish: Gambusia holbrooki Girard, 1859, Pomatochistus microps (Kroyer, 1838) and Aphanius iberus (Valenciennes, 1846). Only small fish (G. holbrooki and A. iberus) were observed in SA.

\section{Sampling}

The ponds were monthly sampled between April and September 2005. This period was selected because it covers the macrophyte development (their growth usually starts in spring and senescence occurs in early autumn), and thus, associated aquatic macroinvertebrates (Sahuquillo et al., 2007). Due to the high evaporation in summer, the 


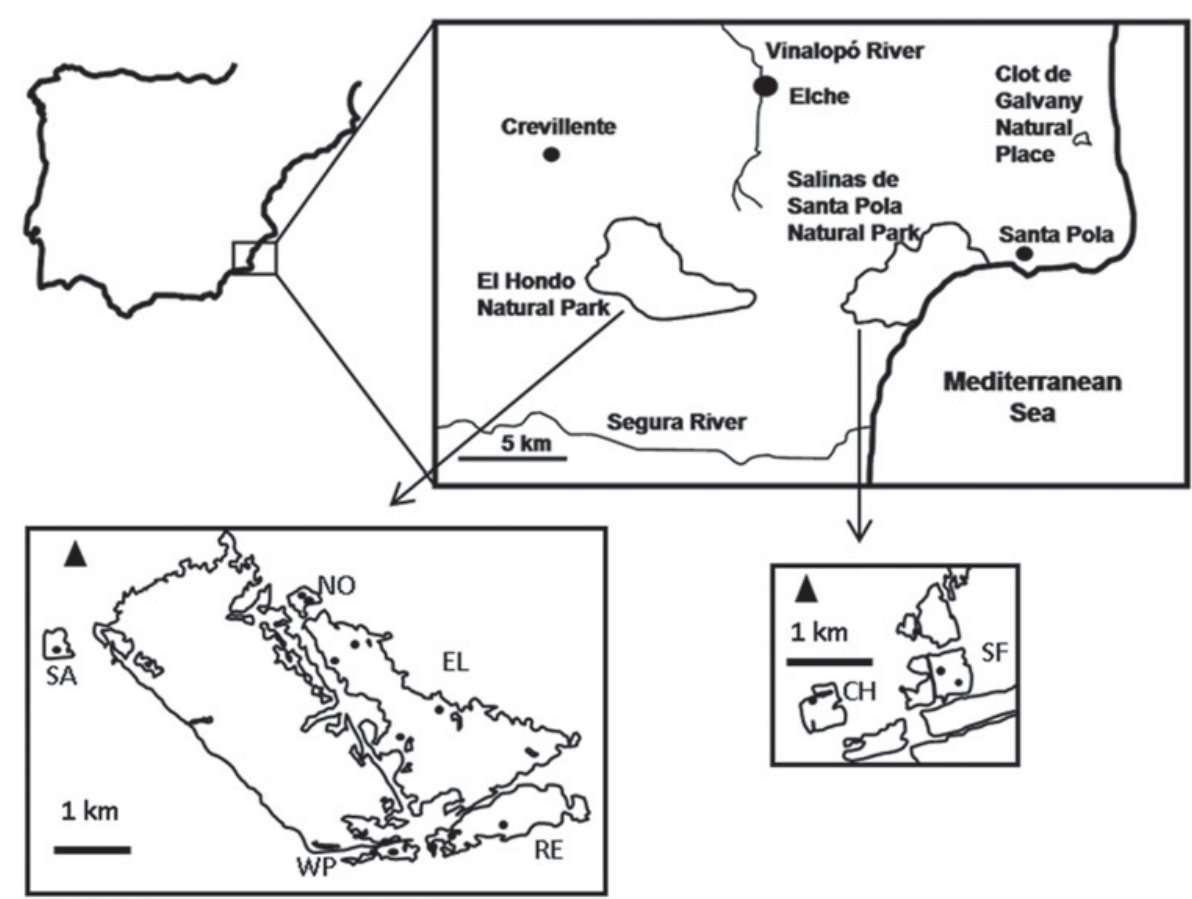

Fig. 1. Map of the study area showing the location of the three protected areas studied (I, El Hondo; II, Salinas de Santa Pola and III, Clot de Galvany), with the detailed position of the ponds and sampling stations (dots) in El Hondo and Santa Pola Natural Parks.

shallowest areas of some ponds (WP1, RE3 and RE5) dried out naturally. EL, used mostly for irrigation, was dried out artificially in May, and then filled and dried again in June; so it was sampled just twice. Water surface of EL increased after filling in June; so two sampling stations were selected in April, whereas four points were sampled in June. According to size and heterogeneity, in some ponds ( $\mathrm{CH}, \mathrm{SA}$ and $\mathrm{GC})$, a station in the center of the lake was selected, while two sampling stations (WP, NO, SF) or three (RE) were chosen in others ponds. Conductivity (VWR EC300), dissolved oxygen (WTW 330i), pH (VWR pH 100), depth and percentage of macrophyte cover through visual inspection were measured. Water transparency was estimated using a Secchi disk, but as all the ponds were very shallow, a Secchi index was also calculated, as the relation of the disk disappearance depth with the total depth, expressed as a percentage (Armengol et al., 2008). Water samples were taken at a $20 \mathrm{~cm}$ depth for chemical and pigment analyses. Ammonium concentration was measured by colorimetry with non-filtered samples. Chlorophyll- $a$ concentration was determined spectrophotometrically in a $90 \%$ acetone extract after filtering the water sample through a Whatman GF/F glass fiber filter, and its concentration was calculated according to Jeffrey and Humphrey (1975). Dissolved phosphate, nitrate and nitrite were measured from filtered samples $(\mathrm{GF} / \mathrm{F})$ by colorimetry (Murphey and Riley, 1962; Golterman et al., 1978; APHA, 1980). A Hitachi U2001 spectrophotometer was used for these measures.

Macroinvertebrate samples were taken using a metacrilate corer (150 cm long and $6.4 \mathrm{~cm}$ diameter) which covered the whole water column. It was introduced vertically into the water and was stuck into the sediment by about $20 \mathrm{~cm}$, so the mud worked as a lid when the corer was taken out. The water above the sediment was poured carefully into a graduated jug to avoid sediment disturbance. Three of these samples were taken and integrated together in each station. The water volume was measured, filtered through a 200- $\mu \mathrm{m}$ mesh and then filters were stored with $70 \%$ ethanol. The sediment was also collected and sieved later in the laboratory through a $1 \mathrm{~mm}$ and a $0.25 \mathrm{~mm}$ mesh size, (more details in Atienzar et al. (2012)). The organisms retained in both sieves, such as the macroinvertebrates that could refuge in the sediment surface, were also counted and added to the list obtained from the water-column samplings.

Zooplankton samples were taken at the same time in each sampling station. A water volume (between two and 10 liters, taken with a jar, in the middle of the water column) was filtered through $30 \mu \mathrm{m}$ mesh filters. The organisms were preserved in $4 \%$ formalin.

Invertebrates were classified and counted using an inverted microscope for zooplankton and a stereomicroscope for macroinvertebrates. With few exceptions, rotifers and crustaceans were identified to species level; whereas insect larvae and adults were only classified until Family. In the case of adult microcrustaceans that were present in both sampling methods, their density was calculated summing the total number of individuals counted in both samples and dividing by the total number of filtered liters in both sampling methods (corer and zooplankton jar). In addition, as the organisms of the water column varied considerably in size, the biomass of 
each taxon at each sampling point and date was estimated. For this purpose, at least 20 organisms, or the total amount if their number was lower, were measured to calculate the dry weight using length-weight relationships (Dumont et al., 1975; Ruttner-Kolisko, 1977; Smock, 1980; Malley et al., 1989; Johnston, 1995; Quintana, 1995). The total biomass for each sampling station and date was calculated for the whole invertebrate assemblage (total biomass), and also for the three groups: microzooplankton, macrozooplankton and macroinvertebrates.

\section{Data analyses}

Canonical correspondence analysis (CCA) was selected to test the influence of environmental variables in species composition at each sampling station. Four different matrices were created: one comprising all the organisms found during the study; one for microzooplankton (rotifers and juvenile copepods); one for macrozooplankton (cladocerans and copepods) and one for macroinvertebrates (large crustaceans and insects). Environmental variables were the same for all the groups, except biomass of the different groups of invertebrates. When analyzing the whole assemblages, the total invertebrate biomass was included, while in the matrices considering only one group, the biomass of the other two groups was included (e.g., in the microcrustacean matrix, the macrozooplankton and macroinvertebrate biomass were included as two different variables). All the variables were transformed, except $\mathrm{pH}$. Macrophyte cover and Secchi index were arcsine square-root transformed and the rest of the variables, including the density of the organisms, were $\log (x+1)$ transformed. Five CCAs, with the environmental and species data were carried out. CCA1 was done with the data of all the studied groups and ponds. CCA2 was performed including only water bodies where fish were present. Then, three more CCAs were performed for each group of invertebrates: microzooplankton (CCA3), macrozooplankton (CCA4) and macroinvertebrates (CCA5). In order to test the relevance of fish (its presence or absence) on the whole community structure, and for each separate group, the explanatory power of this variable was analyzed using variance partitioning. Therefore, a new matrix including the absence (including low densities) and presence of fish was created. The variance explained uniquely by fish was estimated by subtracting the variability explained by environmental variables to the one explained by fish (Lepš and Šmilauer, 2003). In all the CCAs, automatic forward selection of variables was made using Monte Carlo test (499 random permutations) to check the significance of environmental variables, and in each case, the variables with $P<0.1$ were retained. In addition, collinearity of variables was considered throughout the variance inflation factor; so non-collinear variables where those showing an inflation factor below 20 (Lepš and Šmilauer, 2003). To dampen the influence from the species occurring in low numbers, the automatic option to downweight them was selected (downweight of rare species; Lepš and Šmilauer, 2003). Finally, in each analysis, two significance tests were performed (for the first and for all the canonical axes) using a Monte Carlo test (499 permutations).

\section{Results}

A wide range of variability (both spatial and temporal) was observed in the pond surface, conductivity, depth, macrophyte cover or chlorophyll $a$. It is also remarkable the high phosphate and ammonium concentration in GC and EL (Table 1).

A total of 79 invertebrate taxa were found: 51 rotifers, 11 copepods, six cladocerans, five ostracods, four malacostraceans and two insect taxa (chironomid larvae and corixids, which were not identified at the species level). NO1, WP4 and SA presented the highest cumulative richness throughout the period (Fig. 2(a)), with an elevated number of rotifers (27 species). Different species of the genus Brachionus (B. plicatilis, B. ibericus, $B$. quadridentatus brevispinus and $B$. rotundiformis), Colurella adriatica or Hexarthra oxyuris were among the rotifers with the greatest occurrence (Table 2), and all of them showed high densities along the period. The highest number of copepod species was also found in NO1 (seven out of 11 species found in all the studied habitats). Regarding cladocerans, a maximum of six species was reported in EL4: the most abundant was Daphnia magna. This species was found in all the stations, except in six sampling points: RE1, RE3 and the two points in NO and WP (Table 2). In EL, SA and GC, it appeared with other cladoceran species. Five ostracod species were also found, with a maximum of three species in WP4. SA was the pond with the highest malacostracean species richness: the decapod Palaemon elegans, the amphipod Gammarus aequicauda, the isopod Lekanesphaera hookeri and the mysid Mesopodopsis slabberi. None of these large crustaceans were found in EL, GC and RE1. Insects appeared in most sampling points, except chironomids in EL2 and EL6; and corixids in NO2, WP4 and SF (Table 2).

The highest mean richness was found in WP, followed by EL4 and EL8; and the lowest values appeared in SF2, EL2 and GC. Rotifers were always the dominant group in richness (Fig. 2(b)).

RE presented the highest mean density of total zooplankton (Table 3): in points RE3 and RE5 rotifer density was above 7500 ind. $\mathrm{L}^{-1}$, and copepod abundance (juvenile and adults) was more than 1000 ind. $\mathrm{L}^{-1}$. In the majority of the water bodies, rotifers were the most abundant group, showing the highest average densities for some species (Table 2). In EL, juvenile copepods (nauplii and copepodites) were more abundant, and ostracods presented their highest density $\left(3.8\right.$ ind. $\mathrm{L}^{-1}$ in EL2). Insect and malacostracean density ranged from 0 to 2 ind. $\mathrm{L}^{-1}$, except in GC (6 corixids. $\left.\mathrm{L}^{-1}\right)$ and RE3 (5 malacostraceans. $\mathrm{L}^{-1}$ ). 


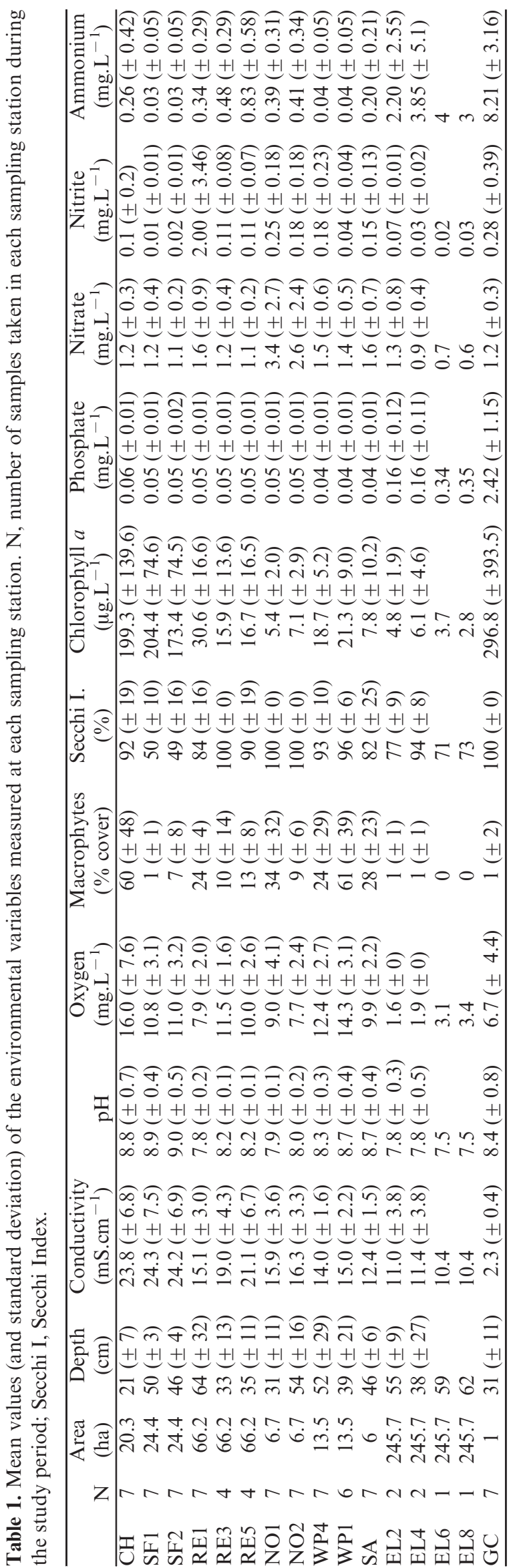

\section{Relationships between invertebrate assemblages and environment}

In the CCA1, performed with the densities of all taxa and ponds, ten environmental variables were selected (Table 4). The first axis accounted for $15.8 \%$ of variance and had a high positive correlation with ammonium and phosphate concentration, and negative with conductivity and dissolved oxygen. The second axis accounted for $8.4 \%$ of variance and was highly correlated with temperature and macrophyte cover (positively), and total biomass (negatively). Both axes were significant $(P<0.01)$. When representing the sampling points in the space limited by the first two axes (Fig. 3(a)), two ponds were clearly separated: GC and EL, correlated with a lower conductivity, high nutrient concentration (phosphate and ammonium) and invertebrate biomass. The other ponds appeared gathered in the center of the figure. Regarding species, in the area where GC and EL were represented, the cladocerans D. magna, Moina micrura and Alona rectangula, the cyclopid Acanthocylops americanus and different species of the genus Brachionus appeared. The only macroinvertebrates associated to these ponds were the insects (corixids and chironomid larvae).

For the CCA2, where only ponds with fish were analyzed, nine variables were selected. The two first axes accounted for a cumulative variance of $19.9 \%$ (Table 4) and both axes were significant $(P<0.01)$. The first one presented a high positive correlation with temperature and macrophyte cover, and negative with biomass. The second axis was positively correlated with conductivity and chlorophyll concentration, and negatively with depth and Secchi. In Figure 3(b), points of SF and $\mathrm{CH}$ are located in the upper part of the graph, together with RE3 and RE5, correlated with conductivity, chlorophyll- $a$ concentration and invertebrate biomass. The other ponds are distributed in the inferior and the right part of the graph, some of them related with macrophytes, temperature, depth or transparency, which may indicate the temporal variation, as these variables showed temporal changes during the study period. Regarding the distribution of species in this space, the malacostraceans (Gammarus aequicauda and M. slabberi) were related to the most saline points $(\mathrm{CH}$ and $\mathrm{SF}$ ), as well as corixids. The only cladoceran species remarked in this analysis was D. magna, associated with deeper and more transparent waters. Copepod juveniles appeared in the center of the graph, as they were found in most of the lakes. Regarding rotifers, species of the genus Lecane were related to waters with a higher temperature and macrophytes, while Hexarthra was related to deeper waters.

When performing the CCAs for each group of invertebrates (microzooplankton, macrozooplankton and macroinvertebrates), some differences were observed (Table 4). Microzooplankton and macrozooplankton assemblages were influenced by similar factors (although with different level of correlation), especially in the first axis: conductivity, phosphate and ammonium concentrations. Nevertheless, for macroinvertebrates ordination, the biomass of 


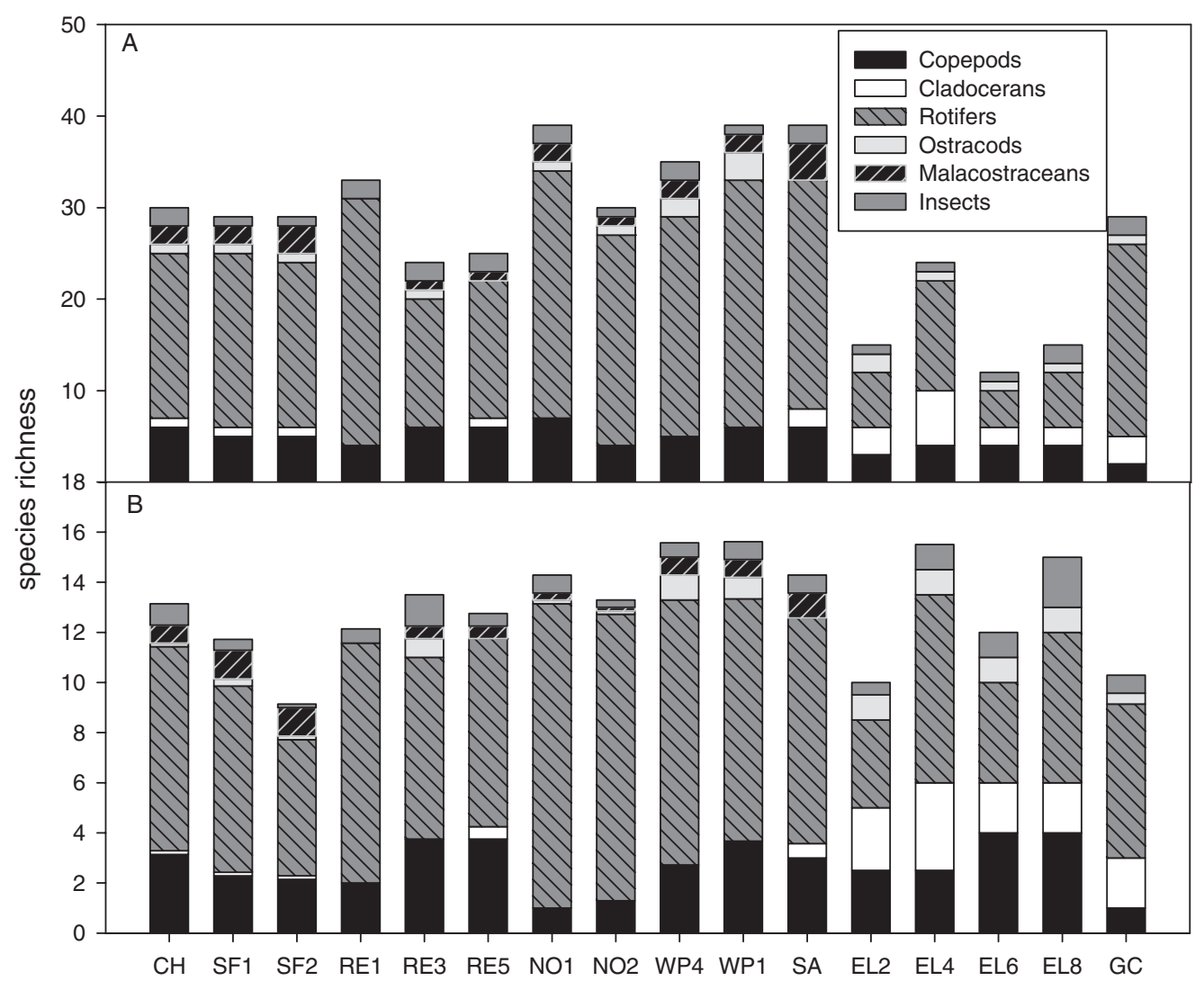

Fig. 2. (a) Cumulative species richness throughout the study period of the main groups of aquatic invertebrates in each sampling point; (b) Mean species richness of the main groups of aquatic invertebrates during all the study period in each sampling point.

microzooplankton and the chlorophyll- $a$ concentration were the most correlated variables with axis 1 .

The effect of fish on the different groups of invertebrates was explored through variance partitioning. Their presence on the total invertebrate assemblages (in all the ponds) explained $8.1 \%$ of the variance. The lowest value of variance explained was found for macroinvertebrates $(1.9 \%)$, followed by microzooplankton $(2.5 \%)$. For macrozooplankton, fish presence represented $21.2 \%$ of the variance.

\section{Variations of biomass and environmental variables}

Three groups of ponds can be distinguished following the temporal patterns (Fig. 4): (i) fishless ponds (EL, GC); (ii) fish ponds from Santa Pola $(\mathrm{CH}, \mathrm{SF})$ and (iii) fish ponds from the El Hondo Natural Park. In fishless ponds (i), a higher relative biomass of macrozooplankton was found; except in late summer when macroinvertebrates and microzooplankton increased their proportion. In Santa Pola ponds (ii), macroinvertebrates dominated from June to August, whereas microzooplankton was the most relevant group the rest of the study period. In fish ponds from El Hondo (iii), microzooplankton showed a higher proportion throughout the period, with a maximum in August and a minimum in July when macroinvertebrates dominated. Regarding environmental variables, the water bodies decreased their depth along the period, except those where water levels were maintained (SF, CH, GC and SA). Macrophytes presented a maximum cover between June and August and they were practically absent from fishless ponds. Chlorophyll $a$ concentration was the highest in fishless ponds and in fish ponds from Santa Pola, where it followed a temporal pattern similar to microzooplankton.

\section{Discussion}

This study highlights the importance of the spatial and temporal heterogeneity in the composition and abundance of invertebrate assemblages and their relevance to promote a high regional diversity in wetlands (Rodrigo et al., 2003). Human activities had also a big influence on these assemblages. In this sense, water bodies in the studied area are good examples of the heavy influence exerted by anthropic activity (input of nutrients, changes in water volume), characteristic of many Mediterranean systems.

\section{Relationships between invertebrate assemblages and environment}

The great concentration of chlorophyll $a$ in some of the water bodies highlights the elevated trophic level in these ecosystems. This is one of the most important indicators 
Table 2. List of those frequent species which appeared in more than ten samples and with a density above 1 ind. $\mathrm{L}^{-1}$, their intervals for average density and their occurrence (Oc.: percentage of the stations where the species appeared in relation to the total number of stations).

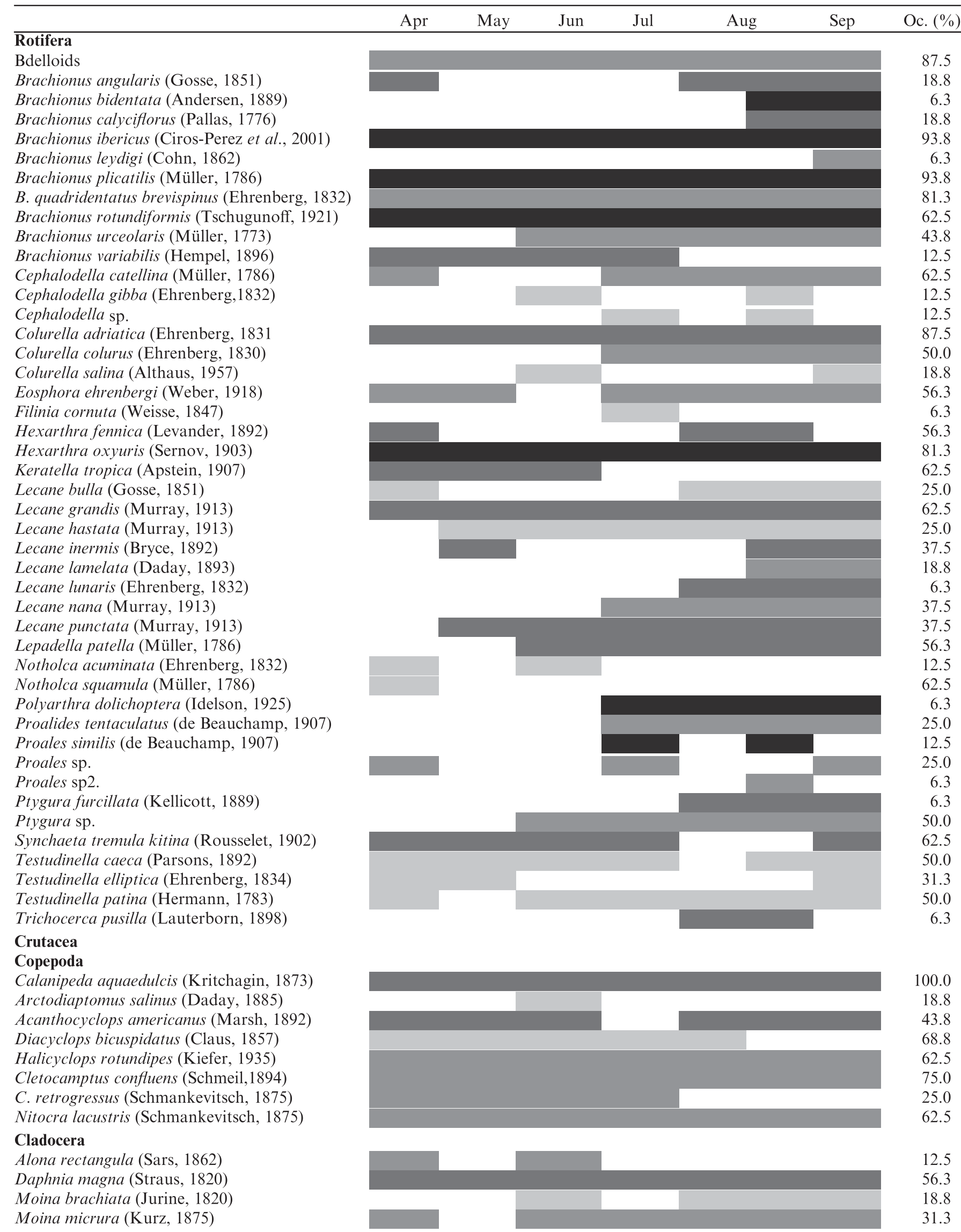


Table 2. (Contd.)

\begin{tabular}{|c|c|c|c|c|c|c|c|c|}
\hline & & & Apr & May & Jun & Jul & Aug & Oc. $(\%)$ \\
\hline \multicolumn{9}{|c|}{ Ostracoda } \\
\hline \multicolumn{8}{|c|}{ Cyprideis torosa (Jones, 1850) } & 37.5 \\
\hline \multicolumn{8}{|c|}{ Heterocypris salina (Brady, 1868) } & 50.0 \\
\hline \multicolumn{8}{|c|}{ Potamocypris villosa (Jurine, 1820) } & 6.3 \\
\hline \multicolumn{9}{|c|}{ Amphipoda } \\
\hline \multicolumn{8}{|c|}{ Gammarus aequicauda (Martynov, 1931) } & 50.0 \\
\hline \multicolumn{9}{|c|}{ Isopoda } \\
\hline \multicolumn{8}{|c|}{ Lekanesphaera hookeri (Leach, 1814) } & 37.5 \\
\hline \multicolumn{9}{|c|}{$\begin{array}{l}\text { Mysidacea } \\
\text { Mesopodopsis slabberi (Van Beneden 1861) }\end{array}$} \\
\hline Mesol & lopsis slabberi (Van & eneden, 1861) & & & & & & 18.8 \\
\hline \multicolumn{9}{|c|}{ Insecta } \\
\hline \multicolumn{9}{|c|}{ Corixidae } \\
\hline \multicolumn{9}{|c|}{ Chironomidae } \\
\hline \multicolumn{9}{|c|}{ Densities (ind. $\mathrm{L}^{-1}$ ): $\square 0-1, \square 1-10, \square 10-100, \square 100-1000$} \\
\hline & Juvenile copepods & Copepods & Cladocerans & & ifers & Ostracods & Malacostraceans & Insects \\
\hline$\overline{\mathrm{CH}}$ & $353.0 \pm 474.6$ & $23.9 \pm 32.7$ & $0.1 \pm 0.2$ & 1798 & \pm 1563.4 & $0.1 \pm 0.2$ & $0.8 \pm 1.1$ & $1.8 \pm 2.9$ \\
\hline SF1 & $73.7 \pm 62.7$ & $9.4 \pm 9.2$ & $0.02 \pm 0.06$ & 606 & 807.4 & $0.1 \pm 0.2$ & $1.2 \pm 1.1$ & $0.2 \pm 0.3$ \\
\hline SF2 & $83.5 \pm 62.8$ & $9.3 \pm 8.9$ & $0.1 \pm 0.2$ & 660 & 886.7 & $0.03 \pm 0.08$ & $2.2 \pm 1.8$ & $0.02 \pm 0.08$ \\
\hline RE1 & $359.3 \pm 538.8$ & $15.8 \pm 22.9$ & 0 & 3441 & \pm 4282.9 & 0 & 0 & $1.1 \pm 2.6$ \\
\hline RE3 & $1101.3 \pm 321.4$ & $142.7 \pm 127.0$ & 0 & 7899 & \pm 3826.6 & $1.6 \pm 1.9$ & $4.9 \pm 9.6$ & $2.3 \pm 2.8$ \\
\hline RE5 & $1202.5 \pm 891.1$ & $60.9 \pm 51.8$ & $0.7 \pm 1.0$ & 7648 & \pm 4374.9 & 0 & $0.6 \pm 0.8$ & $0.3 \pm 0.6$ \\
\hline NO1 & $60.3 \pm 74.8$ & $2.5 \pm 2.1$ & 0 & 308 & \pm 237.3 & $0.1 \pm 0.2$ & $0.1 \pm 0.3$ & $0.3 \pm 0.3$ \\
\hline NO2 & $50.5 \pm 77.6$ & $1.3 \pm 3.2$ & 0 & 348 & \pm 368.7 & $0.1 \pm 0.2$ & $0.04 \pm 0.11$ & $0.4 \pm 0.9$ \\
\hline WP1 & $664.5 \pm 330.1$ & $87.2 \pm 79.9$ & 0 & 4992 & \pm 5857.9 & $2.6 \pm 3.6$ & $1.5 \pm 1.4$ & $1.6 \pm 1.9$ \\
\hline WP4 & $242.5 \pm 204.3$ & $46.2 \pm 55.1$ & 0 & 3420 & \pm 3124.3 & $1.5 \pm 2.4$ & $0.9 \pm 1.4$ & $0.6 \pm 0.8$ \\
\hline SA & $330.0 \pm 336.0$ & $14.3 \pm 12.2$ & $2.7 \pm 4.8$ & 725 & +725.3 & 0 & $0.4 \pm 0.6$ & $0.03 \pm 0.08$ \\
\hline EL2 & $1268.1 \pm 1218.3$ & $26.3 \pm 17.2$ & $194.1 \pm 185.3$ & 340 & +141.4 & $3.8 \pm 4.8$ & 0 & $0.4 \pm 0.6$ \\
\hline EL4 & $1036.1 \pm 246.7$ & $40.1 \pm 6.3$ & $190.1 \pm 155.9$ & 739 & 6885.2 & $3.2 \pm 0.4$ & 0 & $0.3 \pm 0.2$ \\
\hline EL6 & 580.7 & 19.1 & 78.5 & 527 & & $19.2^{-}$ & 0 & $0.4^{-}$ \\
\hline EL8 & 362.3 & 23.1 & 143.7 & 75 & & 8.3 & 0 & 1.3 \\
\hline GC & $643.9 \pm 1061.7$ & $57.6 \pm 91.6$ & $198.6 \pm 246.0$ & 1236 & \pm 1723.2 & $1.2 \pm 3.0$ & 0 & $6.3 \pm 11.3$ \\
\hline
\end{tabular}

for the trophic state, but this parameter has to be taken with prudence in shallow lakes, which can be macrophyte dominated (Canfield et al., 1983). The development of submerged vegetation was great in some ponds, and, since vegetation removes the dissolved nutrients from water, the growth of phytoplankton could be limited, showing low chlorophyll- $a$ concentration in the water (Muylaert et al., 2006). The shallowness of ponds allowed the growth of macrophytes, even in those with high chlorophyll values, given that light could reach the bottom despite the low water transparency.

The concentration of nutrients was also very high in some ponds. They mainly come from sewage waters and runoff from agricultural areas, as found in previous studies in the study area (López and Tomàs, 1989). For example, Rodrigo et al. (2001) calculated an average nitrate concentration of $1.4 \mathrm{mg} . \mathrm{L}^{-1}$ in WP, similar to the values found in the present work. The multivariate analyses revealed that the variables related to trophic state were strongly influencing the invertebrate assemblages, determining the presence of species tolerant to eutrophic conditions, especially micro- and macrozooplankton, as
B. plicatilis (Quintana, 2002) or the invasive copepod A. americanus (Alekseev et al., 2002). In addition, most of the organisms found in ponds with high nutrient level were planktonic (especially abundant were the cladoceran D. magna, the rotifers Polyarthra dolichoptera, Keratella tropica and the genus Brachionus). Some studies point out that eutrophication changes from benthic to pelagic production in water bodies, so planktonic organisms may be favored where nutrient concentrations are high (Vadeboncoeur et al., 2001).

Conductivity is also an important factor structuring invertebrate community (Waterkeyn et al., 2010; AntonPardo and Armengol, 2012), and it showed a wide range in the studied ponds. In general, invertebrate assemblages in the Mediterranean region are characterized by the dominance of a few species, most of them, with a high tolerance to salinity changes (Oltra and Armengol-Díaz, 1999; Badosa et al., 2006). Therefore, aquatic assemblages are dominated by euryhaline species with a wide tolerance to salinity changes, such as Calanipeda aquaedulcis or species of genus Brachionus (Armengol-Díaz et al., 2002; Martinoy et al., 2006). Nevertheless, species not tolerant 
Table 4. Variance explained by the two first axis of all the CCAs performed (CCA1, includes all the studied species and ponds; CCA2, only fish ponds; CCA3, microzooplankton; CCA4, macrozooplankton; CCA5, macroinvertebrates) and correlation coefficients of the selected variables with the two first axis of each CCA.

\begin{tabular}{|c|c|c|c|c|c|c|c|c|c|c|}
\hline & \multicolumn{2}{|c|}{ CCA1 } & \multicolumn{2}{|c|}{ CCA2 } & \multicolumn{2}{|c|}{ CCA3 } & \multicolumn{2}{|c|}{ CCA4 } & \multicolumn{2}{|c|}{ CCA5 } \\
\hline & Axis 1 & Axis 2 & Axis 1 & Axis 2 & Axis 1 & Axis 2 & Axis 1 & Axis 2 & Axis 1 & Axis 2 \\
\hline Variance explained $(\%)$ & & & & & & & & & & \\
\hline of species data & 15.8 & 8.4 & 13.2 & 6.7 & 12.6 & 9.5 & 30.1 & 8.2 & 11.1 & 6.7 \\
\hline of species-environment & 36.7 & 19.4 & 34.7 & 17.9 & 30.3 & 22.8 & 57.4 & 15.6 & 41.4 & 25.2 \\
\hline Correlation & & & & & & & & & & \\
\hline Conductivity & -0.78 & -0.28 & -0.17 & 0.73 & -0.72 & -0.23 & -0.84 & -0.07 & 0.42 & -0.60 \\
\hline Temperature & -0.21 & 0.58 & 0.62 & 0.18 & -0.23 & 0.61 & -0.17 & 0.62 & & \\
\hline Oxygen & -0.61 & 0.01 & & & -0.30 & 0.08 & -0.86 & 0.16 & 0.05 & -0.27 \\
\hline Secchi & 0.06 & -0.24 & -0.22 & -0.71 & 0.00 & -0.21 & & & & \\
\hline Depth & & & & & & & & & -0.81 & 0.19 \\
\hline pSecchi & & & -0.39 & -0.57 & & & 0.10 & -0.60 & & \\
\hline Macrophytes & -0.37 & 0.48 & 0.55 & 0.40 & -0.29 & 0.49 & -0.60 & 0.70 & & \\
\hline Chlorophyll $a$ & 0.05 & -0.01 & -0.20 & 0.78 & 0.25 & -0.02 & -0.08 & 0.28 & 0.50 & 0.34 \\
\hline Phosphate & 0.89 & 0.29 & & & 0.95 & 0.27 & 0.76 & 0.19 & & \\
\hline Nitrate & & & -0.05 & -0.35 & & & & & & \\
\hline Nitrite & -0.04 & 0.34 & 0.26 & -0.12 & 0.04 & 0.35 & 0.00 & 0.03 & & \\
\hline Ammonium & 0.87 & 0.05 & & & 0.78 & -0.05 & 0.90 & 0.11 & -0.32 & 0.25 \\
\hline Total biomass & 0.42 & -0.38 & -0.47 & 0.26 & & & & & & \\
\hline Biomass microz & & & & & & & -0.33 & -0.14 & -0.74 & -0.15 \\
\hline Biomass macroz & & & & & -0.49 & 0.19 & & & & \\
\hline Biomass macroinv & & & & & -0.19 & -0.04 & & & & \\
\hline
\end{tabular}

to these variations will be affected by the increase of conductivity. In our study, the effect of this variable was higher on micro- and macrozooplankton assemblages. Especially, cladocerans were scarce in most of the ponds, probably due to their high conductivity, as this group has a low tolerance to salt concentrations and its richness is lower in brackish waters (Jeppesen et al., 1994; Boronat et al., 2001; Gonçalves et al., 2007). In the majority of ponds, the most abundant species was D. magna, which is tolerant to salinity variations (Ortells et al., 2005). Green et al. (2005) pointed out that the high concentration of pesticides in some of the ponds of the study area, can also explain the absence of cladocerans, a fact that should be further investigated.

\section{Influence of fish}

Fish presence contributed with a relevant percentage of variance to the whole invertebrate assemblages. As expected, the highest effect was found for macrozooplankton assemblages, as fish presence explained an elevated $(21.2 \%)$ percentage of variance, much more important than the effect on microzooplankton and macroinvertebrates. Thus, the presence of planktivorous fish can explain the low abundance or the absence of planktonic cladocerans in most of the ponds (Herzig, 1994; Jeppesen et al., 1994), as due to their big size and slow movements, they are heavily affected by visual predators (Scheffer, 2004). Other potential predators as amphipods or decapods could affect these populations, but with a minor influence (Wilhelm et al., 2000; Persson et al., 2008; Anton-Pardo, 2011). The variations in abundance, richness and composition of cladoceran community can reflect important changes in the ecosystems, such as biotic interactions or alterations of water quality (Kattel, 2012).

In other studies performed in Mediterranean wetlands, planktivorous fish had an important role in the structure of the aquatic assemblages (Compte et al., 2012). In our study, cladocerans were more diverse and appeared in high densities where fish were absent or had low densities (GC and EL). In the ponds where fish were abundant, rotifers were dominant and more diverse, since they are less vulnerable to fish predation (Herzig, 1994; Mittelbach et al., 1995; Williams and Moss, 2003) and due to the cladocerans reduction, they have a reduced resource competition. Most rotifer and cladoceran species are filter feeders, but due to their lower size and filtering efficiency (Gilbert, 1985), the number of rotifer species and their density can be limited due to the competition with cladocerans when fish are absent. Although the presence of fish may increase the number of small species, and thus biodiversity parameters, the absence of large filter feeders has implications on water quality (increase in chlorophyll $a$, decrease in transparency), decreasing the conservation value of these water bodies (e.g., AntonPardo and Armengol, 2012).

On the other hand, macroinvertebrate community was poor in almost all the water bodies, especially in cladoceran-rich ponds, where only aquatic insects and ostracods appeared. However, in ponds with lower macrozooplankton biomass, macroinvertebrate community was more abundant and diverse. Connected with this, microzooplankton biomass was selected as significant variable in the CCA5 (macroinvertebrates), as rotifers and other small taxa presented higher biomass in those 
a)
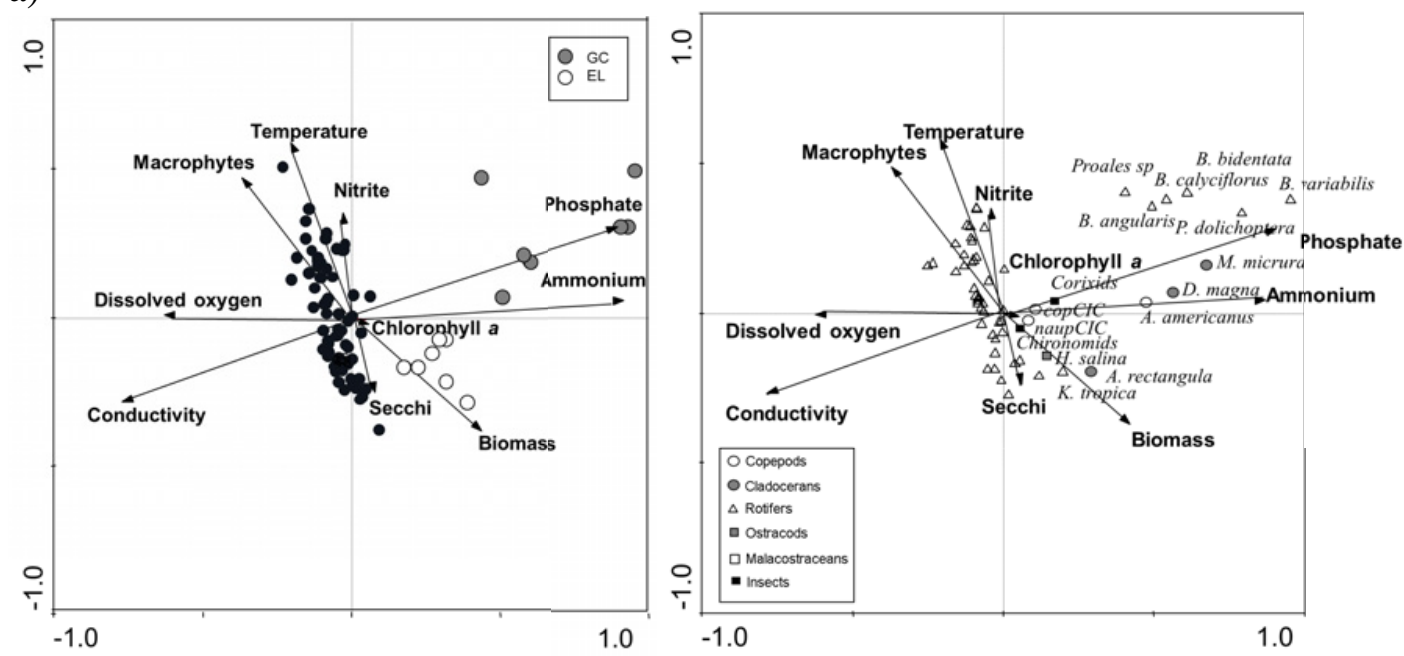

b)
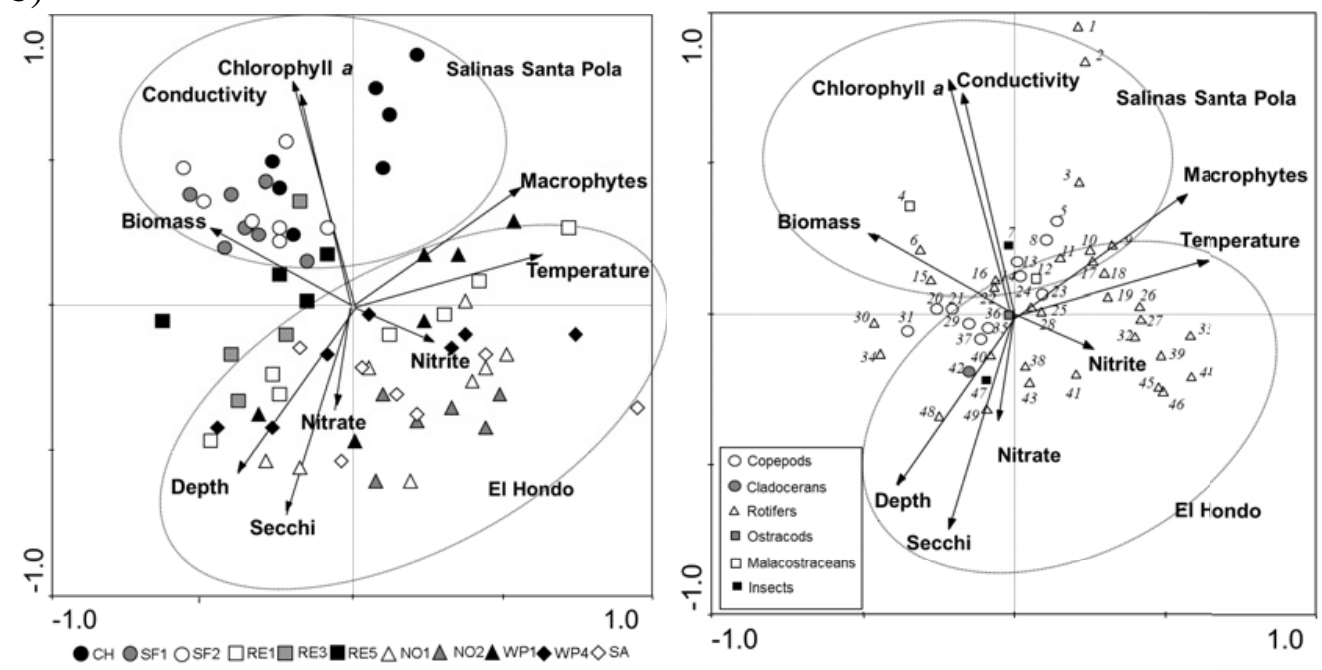

Fig. 3. CCA1 (a) and CCA2 (b) ordination diagrams; biplot showing the sampling points (left) and the species position (right) in relation to the environmental variables in the space formed by the two main axes in each CCA. For CCA2, the numbers correspond to the following species: 1. Proales sp.; 2. P. similis; 3. L. inermis; 4. M. slabberi; 5. H. rotundipes; 6. T. caeca; 7. Corixids; 8. N. lacustris; 9. L. grandis; 10. C. colurus; 11. C. catellina; 12. G. aequicauda; 13. Cyclopoid copepodids; 14. Nauplii harpacticoids; 15. B. plicatilis; 16. S. tremula; 17. Ptygura sp.; 18. L. lamellata; 19. E. ehrenbergi; 20. D. bicuspidatus odessanus; 21. Calanoid copepodids; 22. B. ibericus; 23. C. confluens; 24. Harpacticoid copepodids; 25. B. rotundiformis; 26. B. urceolaris; 27. L. patella; 28. C. adriatica; 29. Nauplii cyclopoids; 30. N. squamula; 31. C. retrogressus; 32. P. furcillata; 33. L. nana; 34. H. fennica; 35. C. aquaedulcis; 36. H. salina; 37. Nauplii calanoids; 38. H. oxyuris; 39. L. punctata; 40. Bdelloidea; 41. B. quadridentatus brevispinus; 42. D. magna; 43. B. leydigi; 44. T. pusilla; 45. L. hastata; 46. L. luna; 47. Chironomids; 48. K. tropica; 49. T. patina.

ponds where macrozooplankton biomass was low and macroinvertebrates were more abundant. Conductivity may also influence the macroinvertebrate distribution, since malacostraceans are more tolerant to high salt concentrations (Piscart et al., 2005; Boix et al., 2008). In addition, macroinvertebrate assemblages in brackish warm lakes are poorer than in temperate regions, especially free-swimming invertebrates, probably due to the higher predation pressure (Brucet et al., 2012). However, the malacostracean species, found mainly in the ponds with fish, are faster swimmers and have benthic behavior, so they could reduce the influence of fish predation near the sediment or among vegetation. The absence of this group in fishless ponds (which were also the ones with high trophic level) could be caused by the shift from benthic to pelagic production as mentioned above, but also because of the lack of macrophytes. The sampling methodology used for large invertebrates (corer) could also have some limitations when sampling insects with high mobility in the water column, as these active taxa are more difficult to detect with usual sampling techniques for planktonic organisms (Florencio et al., 2012). Malacostraceans presented the highest richness in the recently created pond SA, which had total richness values similar to the 

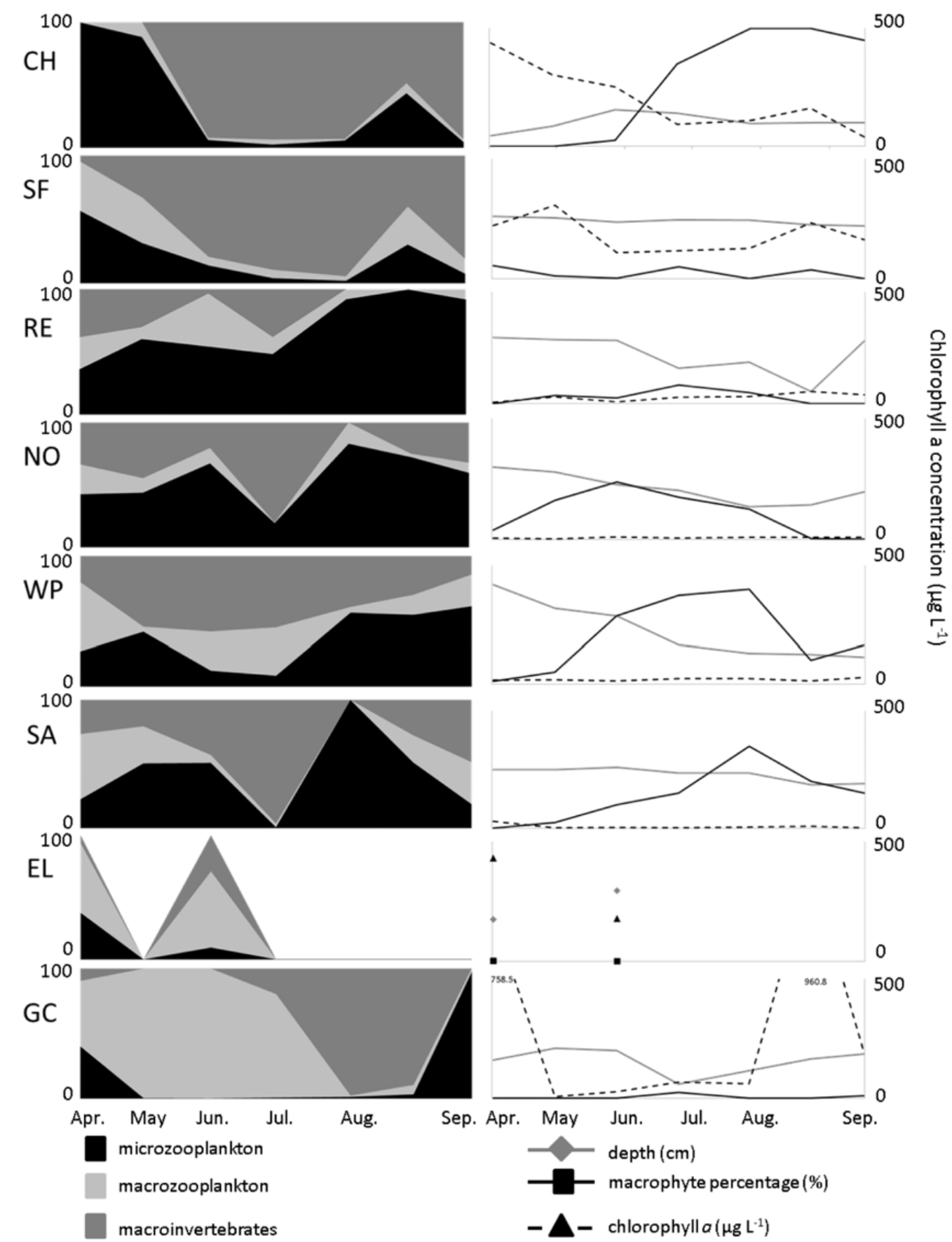

Fig. 4. Temporal variations in biomass of the three main groups (left) and selected environmental variables (right) in each pond (in ponds with more than a sample point these values have been averaged for every sampling date).

other ponds. The only presence of small fish species (G. holbrooki and A. iberus), could explain the fact that large crustaceans are more diverse in this water body. In addition, the pond is connected with the water source (aquifer) through surface canals, which at the same time are connected with other water bodies in the area. This fact, together with the high abundance of waterbirds, might facilitate the arrival and exchange of species to new habitats (this ponds was only four years old) in a short period of time, even those passive dispersal taxa (Figuerola and Green, 2002).

\section{Variations of biomass and environmental variables}

According to the observed temporal changes, an important variable is the relative abundance of macrophytes. It is linked with the appearance of some littoral species usually associated with vegetation, such as isopod Lekanesphaera hookeri or with several rotifer species of the genus Lecane (Koste, 1978; Tachet et al., 2003). Vegetation, as well as conductivity, presented an important temporal variation throughout the studied period, increasing the habitat complexity in the water bodies, and 
thus, influencing invertebrate assemblages. For this reason, samplings carried out at different moments of the annual cycle are important to evaluate accurately the diversity of these variable habitats (Fahd et al., 2007; Sahuquillo and Miracle, 2010). In our case, the samplings were carried out considering different moments of the growing season of macrophytes in this area, which are important for invertebrates.

The variation in biomass with time highlights the interactions among the different groups of invertebrates. As mentioned above, the increase in macrozooplankton biomass (mainly cladocerans) is related with a decrease in microzooplankton biomass probably due to competitive interactions. Therefore, in ponds where macrozooplankton was abundant, microzooplankton was dominated by juvenile copepods and only a few species of rotifers (widespread taxa as Brachionus spp., Hexarthra spp., $K$. tropica, etc.).

\section{Conclusions and implications}

In conclusion, the marked temporal and spatial heterogeneity of environmental variables found in the studied wetlands, promotes a high regional diversity. Human activity was an important factor influencing this heterogeneity and thus, invertebrate community composition. The input of nutrients and the manipulation of the water level give a set of different environmental conditions which promotes particular assemblages. These disturbances affected all the groups, but especially micro- and macrozooplankton. This is shown by the fact that water bodies under these impacts presented a community composed by species tolerant to high nutrient concentrations, and where large benthic organisms were scarce. Fish also influenced invertebrate assemblages, particularly macrozooplankton, as fishless ponds presented abundant cladocerans in their assemblages, with lesser relevance of microzooplankton and macroinvertebrates. Variations in the water level, increase in conductivity and the development of vegetation throughout the period were remarkable. These changes affect the distribution of organisms tolerant to salinity variations and those more associated to a substrate (vegetation or sediment). Through the study of the whole invertebrate assemblages in the water column of very shallow waters, the interactions among different groups, and between benthic and pelagic processes, could be remarked. Besides natural variations, human activity can be an important source of change. In extreme cases, such disturbance (e.g., changes in water level) could threaten some habitats. If this is not reversed, our results imply that taxa resistant to such variations would be favored, homogenizing invertebrate local assemblages across the region. On the other hand, the creation of new habitats is an important strategy to preserve aquatic diversity in regions subjected to high anthropic pressure.

Acknowledgements. This study has been supported by the Conselleria de Territori i Habitatge of Generalitat Valenciana, through a European Union Project (LIFE2000NAT/E/007311). Final data processing was supported by the project of the South Bohemian Research Center of Aquaculture and Biodiversity of Hydrocenoses, Grant No. CENAKVA CZ.1.05/2.1.00/01.0024 and project CZ.1.07/2.3.00/30.0006. The results of the project LO1205 were obtained with a financial support from the MEYS of the CR under the NPU I program. We wish to thank the workers from the El Hondo and Santa Pola Natural Parks and from the El Clot de Galvany Local Natural Place, the Limnology Group and the Integrative Ecology Group at the Cavanilles Institute. R. Ortells and C. Fito collaborated in field and laboratory tasks, and A. Sanz, J. Rueda, F. Mezquita and L. Zamora helped us to classify some of the organisms. We also thank F. Mezquita for statistical advice and two anonymous reviewers who provided valuable comments on an early version of this manuscript.

\section{References}

Alekseev V., Fefilova E. and Dumont H.J., 2002. Some noteworthy freeliving copepods from surface freshwater in Belgium. Belg. J. Zool., 132, 133-139.

Anton-Pardo M., 2011. Influencia de factores bióticos y abióticos sobre el zooplankton de dos zonas litorales sometidas a importantes efectos antrópicos. Dissertation, University of Valencia, 294 p.

Antón-Pardo M. and Armengol X., 2010. Zooplankton community from restored peridunal ponds in the Mediterranean region (L'Albufera Natural Park, Valencia, Spain). Limnetica, 29, 133-143.

Anton-Pardo M. and Armengol X., 2012. Effects of salinity and water temporality on zooplankton community in coastal Mediterranean ponds. Estuar. Coast. Shelf S., 114, 93-99.

APHA, 1980. Standard Methods for the Examination of Water and Wastewater, American Public Health Association, Washington, DC, $1268 \mathrm{p}$.

Armengol X., Antón-Pardo M., Atiénzar F., Echevarrías J.L. and Barba E., 2008. Limnological variables relevant to the presence of the endangered white-headed duck in Southeastern Spanish wetlands during a dry period. Acta Zool. Acad. Sci. Hung., 54, 45-60.

Armengol-Díaz X., Rodrigo M.A. and Oltra R., 2002. Caracterización del zooplancton de la zona sur del Parque Natural del Hondo (Alicante). Ecología, 16, 243-257.

Atienzar F., Antón-Pardo M., Armengol X. and Barba E., 2012. Distribution of the white-headed duck Oxyura leucocephala is affected by environmental factors in a Mediterranean wetland. Zool. Stud., 51, 783-792.

Badosa A., Boix D., Brucet S., López-Flores R. and Quintana X.D., 2006. Nutrients and zooplankton composition and dynamics in relation to the hydrological pattern in a confined Mediterranean salt marsh (NE Iberian Peninsula). Estuar. Coast. Shelf Sci., 66, 513-522.

Boix D., Sala J., Gascón S., Martinoy M., Gifre J., Brucet S., Badosa A., López Flores R. and Quintana X.D., 2007. Comparative biodiversity of crustaceans and aquatic insects from various water body types in coastal Mediterranean wetlands. Hydrobiologia, 584, 347-359.

Boix D., Gascón S., Sala J., Badosa A., Brucet S., López Flores R., Martinoy M., Gifre J. and Quintana X.D., 2008. 
Patterns of composition and species richness of crustaceans and aquatic insects along environmental gradients in Mediterranean water bodies. Hydrobiologia, 597, 53-69.

Boronat L., Miracle M.R. and Armengol X., 2001. Cladoceran assemblages in a mineralization gradient. Hydrobiologia, 442, 75-88.

Brooks J.L. and Dodson S.I., 1965. Predation, body size, and composition of plankton. Science, 150, 28-35.

Brucet S., Boix D., Nathansen L.W., Quintana X.D., Jensen E., Balayla D., Meerhoff M. and Jeppesen E., 2012. Effects of temperature, salinity and fish in structuring the macroinvertebrate community in shallow lakes: implications for effects on climate change. PLoS ONE, 7, E30877.

Burks R.L., Lodge D.M., Jeppesen E. and Lauridsen T.L., 2002. Diel horizontal migration of zooplankton: costs and benefits of inhabiting the littoral. Freshw. Biol., 47, 343-365.

Canfield D.E. Jr., Langeland K.A., Maceina M.J., Haller W.T., Shireman J.V. and. Jones J.R., 1983. Trophic state classification of lakes with aquatic macrophytes. Can. J. Fish. Aquat. Sci., 40, 1713-1718.

Claps M.C., Gabellone N.A. and Benítez H.H., 2011. Seasonal changes in the vertical distribution of rotifers in a eutrophic shallow lake with contrasting states of clear and turbid water. Zool. Stud., 50, 454-465.

Compte J., Gascón S., Quintana X.D. and Boix D., 2012. The effects of small fish presence on a species-poor community dominated by omnivores: example of a size-based trophic cascade. J. Exp. Mar, Biol. Ecol., 418-419, 1-11.

Doi H., Chang K-H., Nishibe Y., Imai H. and Nakano, S-i., 2013. Lack of congruence in species diversity indices and community structures of planktonic groups based on local environmental factors. PLOS ONE, 8, e69594.

Dumont H., Van de Velde I. and Dumont S., 1975. The dry weight estimate of biomass in a selection of cladocera, copepoda and rotifera from the plankton, periphyton and benthos of continental waters. Oecologia, 19, 75-97.

Fahd K., Florencio M., Keller C. and Serrano L., 2007. The effect of sampling scale on zooplankton community assessment and its implications for the conservation of temporary ponds in south-west Spain. Aquat. Conserv., 17, 175-193.

Figuerola J. and Green A.J., 2002. Dispersal of aquatic organisms by waterbirds: a review of past research and priorities for future studies. Freshw. Biol., 47, 483-494.

Florencio M., Diaz-Paniagua C., Gomez-Mestre I. and Serrano L., 2012. Sampling macroinvertebrates in a temporary pond: comparing the suitability of two technics to detect richness, spatial segregation and diel activity. Hydrobiologia, 689, 121-130.

Frisch D., Moreno-Ostos E. and Green A.J., 2006. Species richness and distribution of copepods and cladocerans and their relation to hydroperiod and other environmental variables in Doñana, south-west Spain. Hydrobiologia, 556, 327-340.

García-Criado F. and Trigal C., 2005. Comparison of several techniques for sampling macroinvertebrates in different habitats of a North Iberian pond. Hydrobiologia, 545, 103-115.

Gilbert J.J., 1985. Competition between rotifers and Daphnia. Ecology, 66, 1943-1950.

Golterman H.L., Clymo R.S. and Ohnstad M., 1978. Methods for Physical and Chemical Analysis of Freshwaters. IBP Handbook no 8, Blackwell Scientific Publications, Oxford, $213 \mathrm{p}$.
Gonçalves A.M.M., Castro B.B., Pardal M.A. and Gonçalves F., 2007. Salinity effects on survival and life history of two freshwater cladocerans (Daphnia magna and Daphnia longispina). Ann. Limnol. - Int. J. Lim., 43, 13-20.

Green A.J., Fuentes C., Moreno-Ostos E. and Rodrigues da Silva S.L., 2005. Factors influencing cladoceran abundance and species richness in brackish lakes in Eastern Spain. Ann. Limnol. - Int. J. Lim., 41, 73-81.

Grillas P., Gauthier P., Yavercovski N. and Perennou C., 2004. Mediterranean Temporary Ponds. Volume 1- Issues Relating to Conservation, Functioning and Management, Tour du Valat, France, 122 p.

Hall D.J., Threlkeld S.T., Burns C.W. and Crowley P.H., 1976. The size-efficiency hypothesis and the size structure of zooplankton communities. Annu. Rev. Ecol. Syst., 7, 177-208.

Herzig A., 1994. Predator-prey relationships within the pelagic community of Neusiedler See. Hydrobiologia, 275/ 276, 81-96.

Jeffrey E. and Humphrey G.F., 1975. New spectrophotometric equations for determining chlorophylls a, b, c1 and c2 in higher plants, algae and natural phytoplankton. Biochem. Physiol. Pflanzen, 167, 91-194.

Jeppesen E., Søndergaard M., Kanstrup E., Petersen B., Eriksen R.B., Hammershøj M., Mortensen E., Jensen J.P. and Have A., 1994. Does the impact of nutrients on the biological structure and function of brackish and freshwater lakes differ? Hydrobiologia, 275/276, 15-30.

Jiménez J., Lacomba I., Sancho V. and Risueño P., 2002. Peces continentales, anfibios y reptiles de la Comunidad Valenciana, Generalitat Valenciana, Valencia, 271 p.

Johnston T.A., 1995. Food limitation during early life history of walleye (Stizostedion vitreum). Dissertation, University of Manitoba, $256 \mathrm{p}$.

Kattel G.R., 2012. Can we improve management practice of floodplain lakes using cladoceran zooplankton? River Res. Appl., 28, 1113-1120.

Koste W., 1978. Rotatoria. Die rädertiere Mitteleuropas. Monogonta, Gerbrüder Bortraeger, Berlin, 671 p.

Lepš J. and Šmilauer P., 2003. Multivariate Analysis of Ecological Data using CANOCO, Cambridge University Press, Cambridge, UK, 269 p.

López M.P. and Tomàs X., 1989. Chemical composition of the small coastal lagoons of the Mediterranean Spanish litoral. Sci. Mar., 53, 591-599.

Malley D.F., Lawrence S.G., MacIver M.A. and Findlay W.J., 1989. Range of variations in estimates of dry weight for planktonic Crustacea and Rotifera from temperate North American lakes. Canadian Technical Report of Fisheries and Aquatic Sciences 1666, 49 p.

Martinoy M., Boix D., Sala J., Gascón S., Gifre J., Algerich A., Barrera R., Brucet S., Badosa A., López-Flores R., Méndez M., Utgé J.M. and Quintana X.D., 2006. Crustacean and aquatic insect assemblages in the Mediterranean coastal ecosystems of Empordà wetlands (NE Iberian peninsula). Limnetica, 25, 665-682.

Meerhoff M., Iglesias C., De Mello F.T., Clemente J.M., Jensen E., Lauridsen T.L. and Jeppesen E., 2007. Effects of habitat complexity on community structure and predator avoidance behaviour of littoral zooplankton in temperate versus subtropical shallow lakes. Freshw. Biol., 52, 1009 1021. 
Mittelbach G.G., Turner A.M., Hall D.J., Rettig J.E. and Osenberg C.W., 1995. Perturbation and resilience: a long-term whole-lake study of predator extinction and reintroduction. Ecology, 76, 2347-2360.

Murphey J. and Riley J.A., 1962. A modified single-solution method for the determination of phosphate in natural waters. Anal. Chim. Acta, 27, 31-36.

Muylaert K., Declerck S., Van Wichelen J., De Meester L. and Vyverman W., 2006. An evaluation of the role of daphnids in controlling phytoplankton biomass in clear water versus turbid shallow lakes. Limnologica, 36, 69-78.

Nielsen D.L., Hillman T.J., Smith F.J. and Shiel R.J., 2002. The influence of seasonality and duration of flooding on zooplankton in experimental billabongs. River Res. Appl., 18, 227-237.

Oltra R. and Armengol-Díaz X., 1999. Limnología de los humedales mediterráneos susceptibles de albergar samaruc y fartet: (II) zooplancton. In: Planelles M. (ed.) Peces Ciprinodóntidos ibéricos. Fartet y Samaruc, Generalitat Valenciana, Valencia, $357 \mathrm{p}$.

Ortells R., Reusch T.B.H. and Lampert W., 2005. Salinity tolerance in Daphnia magna: characteristics of genotypes hatching from mixed sediments. Oecologia, 143, 509-516.

Pearce F. and Crivelli A.J., 1994. Characteristics of Mediterranean Wetlands, Tour du Valat, France, 90 p.

Persson M., Andersson S., Baden S. and Moksnes P.O., 2008. Trophic role of the omnivorous grass shrimp Palemon elegans in a Swedish eelgrass system. Mar. Ecol.-Prog. Ser., 371, 203-212.

Piscart C., Moreteau J.C. and Beisel J.N., 2005. Biodiversity and structure of macroinvertebrate communities along a small permanent salinity gradient (Meurthe River, France). Hydrobiologia, 551, 227-236.

Quintana X.D., 1995. Relaciones entre el peso y la longitud en Aedes, Culex y Gammarus. Limnetica, 11, 15-17.

Quintana X.D., 2002. Measuring the intensity of disturbance in zooplankton communities of Mediterranean salt marshes using multivariate analysis. J. Plankton Res., 24, 255-265.

Quintana X.D., Boix D., Badosa A., Brucet S., Compte J., Gascón S., López-Flores R., Sala J. and Moreno-Amich R., 2006. Community structure in Mediterranean shallow lentic ecosystems: size-based vs. taxon-based approaches. Limnetica, 25, 303-320.

Rennie M.D. and Jackson L.J., 2005. The influence of habitat complexity on littoral invertebrate distributions: patterns differ in shallow prairie lakes with and without fish. Can. J. Fish Aquat. Sci., 62, 2088-2099.
Rodrigo M.A., Armengol-Díaz X., Oltra R., Dasí M.J. and Colom W., 2001. Environmental variables and planktonic communities in two ponds of El Hondo wetland (SE Spain). Int. Rev. Hydrobiol., 86, 299-315.

Rodrigo M.A., Rojo C. and Armengol X., 2003. Plankton biodiversity in a landscape of shallow water bodies (Mediterranean coast, Spain). Hydrobiologia, 506-509, 317-326.

Romare P., Berg S., Lauridsen T. and Jeppesen E., 2003. Spatial and temporal distribution of fish and zooplankton in a shallow lake. Freshw. Biol., 48, 1353-1362.

Ruttner-Kolisko A., 1977. Suggestion for biomass calculations of plankton rotifers. Arch. Hydrobiol. Beih. Ergebn. Limnol., $8,71-76$.

Sahuquillo M. and Miracle M.R., 2010. Crustacean and rotifer seasonality in a Mediterranean temporary pond with high diversity (Lavajo de Abajo de Sinarcas, Eastern Spain). Limnetica, 29, 75-92.

Sahuquillo M., Poquet J.M., Rueda J. and Miracle M.R., 2007. Macroinvertebrate communities in sediment and plants in coastal Mediterranean water bodies (Central Iberian Peninsula). Ann. Limnol.-Int. J. Lim., 43, 117-130.

Scheffer M., 2004. Ecology of Shallow Lakes, Kluwer Academic Publishers, The Netherlands. 357 p.

Smock L.A., 1980. Relationships between body size and biomass of aquatic insects. Freshw. Biol., 10, 375-383.

Tachet H., Richoux P., Bournaud M. and Usseglio-Polatera P., 2003. Invertébrés d'eau douce; systématique, biologie, écologie. CNRS Éditions, Lyon, 585 p.

Vadeboncoeur Y., Lodge D.M. and Carpenter S.R., 2001. Whole-lake fertilization effects on distribution of primary production between benthic and pelagic habitats. Ecology, 82, 1065-1077.

Viñals M.J., Colom W., Rodrigo T., Dasí M.J., Armengol J., Oltra R. and Miracle R., 2001. Rasgos característicos de un humedal mediterráneo artificializado y su problemática ambiental: El Hondo de Elche (Alicante, España). Humedales Mediterráneos, 1, 147-154.

Waterkeyn A., Vanschoenwinkel B., Grillas P. and Brendonck L., 2010. Effect of salinity on seasonal communiy patterns of Mediterranean temporary wetland crustaceans: A mesocosm study. Limnol. Oceanogr., 55, 1712-1722.

Wilhelm F.M., Schindler D.W. and McNaught A.S., 2000. The influence of experimental scale on estimating the predation rate of Gammarus lacustris (Crustacea: Amphipoda) on Daphnia in an alpine lake. J. Plankton Res., 22, 1719-1734.

Williams A.E. and Moss B., 2003. Effects of different fish species and biomass on plankton interactions in a shallow lake. Hydrobiologia, 491, 331-346. 